\title{
"DAHNTAHN" PITTSBURGH: MONOPHTHONGAL /aw/ AND REPRESENTATIONS OF LOCALNESS IN SOUTHWESTERN PENNSYLVANIA
}

\author{
BARBARA JOHNSTONE, NEETA BHASIN, \\ and DENISE WITTKOFSKI
}

Carnegie Mellon University

$\mathrm{I}_{\mathrm{N}}$ monophthongization of the diphthong /aw/ in Pittsburgh, Pennsylvania. We suggest that the persistence of this feature may be linked to the dominant role it plays in print representations of local-sounding speech. In sketching the history of the variable (aw) in the speech of working-class male Pittsburghers as far back as $185^{\circ}$ or so, this study contributes to the small body of descriptive and historical research about the North Midland speech of Pittsburgh and southwestern Pennsylvania. In addition, the study contributes to the growing sociolinguistic literature exploring the linguistic correlates of the rapid social and economic changes of the last few decades and their effects on people's senses of self and place (Bailey et al. 1993; Lane 1998; Schilling-Estes 1998; Beal 1999; Milroy and Watt 1999; Dyer 2000; Røyneland 2000).

In what follows, we provide evidence for two claims. First, we describe exploratory work that suggests that the use of the monophthongal variant of the diphthong /aw/ (as in [at] for out or [dantan] for downtown) by white, working-class male Pittsburghers is not disappearing, as might be expected on some grounds. Second, we show that of all the features of local speech that are the object of local stereotyping (Labov 1972, 180; Labov 2001, 196-97), the monophthongal pronunciation of /aw/ is by far the most salient, as measured by the frequency with which it is represented in the popular print media via nonstandard spelling. Pittsburghers tell each other over and over, in newspaper cartoons, editorials, and articles, on t-shirts and refrigerator magnets, and in occasional explicit public debate about the role local speech should play in local life, that "real Pittsburghers" say "dahntahn" for downtown, "aht" for out, and so on. At this point we can only suggest that the trajectory of monophthongal /aw/ in Pittsburgh may have 
something to do with the role of this feature in local discourse about localness; we cannot demonstrate a causal connection between the persistent usage of the feature by younger speakers and its frequent representation in the local media, nor can we rule out other linguistic and social factors that may also help account for the feature's persistence. But the study suggests how representations of local- or regional-sounding speech may enter into the ideological process by which certain speech forms can come to index local identities, and how this process may intersect with the sometimes competing leveling pressures created by dialect contact.

This study was designed not only to begin an exploration of a new research site (Pittsburgh) and a new set of research questions, but also as a pedagogical endeavor. In this respect, the study illustrates the usefulness of documentary film as data for at least the exploratory phase of historical dialectology. Using film as data, instead of doing fieldwork, made it possible to carry out all of the theoretical framing and preliminary analysis for this project in the course of one semester, in a seminar for advanced undergraduates and graduate students with no background in linguistics. The study, and the course, were originally framed as an exploration of the "rhetoric of place." We worked inward from theories of place and identity and the larger-scale socioeconomic context of globalization and localization to the more particular context of local linguistic history and the details of phonetic variability. This made the project appealing to students who might not have thought of taking a course in historical dialectology and who were mostly unaccustomed to the discipline required for the systematic, carefully grounded research plan we developed, but who already knew they liked social theory and film. Two of the graduate students from that seminar continued to work on the project and are coauthors of this report.

\section{HISTORICAL SKETCH OF PITTSBURGH AND PITTSBURGH SPEECH}

Pittsburgh is located in southwestern Pennsylvania, on the western edge of what Pittsburghers (along with most other Americans) think of as the Northeast, but across the Allegheny Mountains from the other large Northeastern cities. At the turn of the twentieth century, Pittsburgh was arguably the industrial hub of the United States, home to Andrew Carnegie's virtual monopoly on steel production as well as to some of the country's first and largest aluminum, glass, and electrical equipment companies. 
Following the French and Indian War during the latter half of the eighteenth century, when Native Americans and French and British armies battled for control of the Ohio River valley, southwestern Pennsylvania was settled by Scotch-Irish and Germans (Dunaway 1944). By the late nineteenth century, the region was attracting many immigrants from eastern Europe, Italy, and elsewhere, as well as African Americans from the South, who came to work in the mills and mines and on the railroads (Baldwin 1937). These people typically moved into ethnic enclaves near their workplaces, isolated from one another by the area's hills, ravines, and rivers as well as by linguistic and cultural barriers, and isolated from the rest of the state by the Allegheny Mountains, by distance from the east coast, and by virtue of the fact that most were too poor to travel. Partly for these reasons, Pittsburghers' traditional affiliations are with their neighborhood ethnic groups and with the city (familiarly known as "the Burgh"), rather than with the state or the larger region. Natives would be more likely to identify themselves as Pittsburghers than as Pennsylvanians or as Northerners, and there is a firmly entrenched belief that there is a way of talking that is unique to the city. This is referred to as "Pittsburghese." Although the term "Pittsburghese" appears to date from the 1960s, articles describing turns of phrase and words, sounds, and structures thought (usually erroneously) to exist only in Pittsburgh speech have appeared in the local press since at least 1910 (Johnstone and Danielson 2001).

Pittsburgh's economy boomed in the twentieth century until after World War II, but once it became feasible to produce steel and other products more cheaply elsewhere, heavy industry began to leave Pittsburgh and the rest of the "rustbelt," along with the jobs it had provided. The population of Allegheny County, which includes most of the Pittsburgh metropolitan area, peaked at around two million between 1940 and $195^{\circ}$; according to 2000 census figures, it is now around 1,280,000, and the population is on average elderly (U.S. Census Bureau 2001a, 2001b; WQED/Pittsburgh 2001). Although the headquarters of USX (steel), Alcoa (aluminum), PPG (glass), and Heinz foods remain in Pittsburgh and some manufacturing continues in the area, the largest employer is now the University of Pittsburgh with its network of health-care services.

Scholarly research about varieties of English spoken in Pittsburgh and southwestern Pennsylvania (Kurath 1949, 35-36; Kurath and McDavid 1961, 17-18; Hankey 1965a, 1965b, 1972; Brown 1982; Gagnon 1999; McElhinny 1999) points to a number of phonological, lexical, and morphosyntactic features of local speech. Two fairly distinctive phonological characteristics of the variety, which may in fact be phonologically related to each other, are the merger of $/ \mathrm{a} /$ and $/ \mathrm{J} /$, with the resulting single phoneme 
realized as a rounded [ 0 ], and the monophthongization of /aw/. While the merger of the low back vowels /a/ and / $/$ / is widespread in the United States, the single phoneme resulting from the merger is more often realized elsewhere with a more fronted, unrounded vowel more like [a]. The pattern heard in southwestern Pennsylvania, where the realization of the merged vowel is rounded and backed ([o] rather than [a]), means that [a] is available as a realization for /aw/. In other words, while Don and Dawn often sound the same in Pittsburgh-[don]-they do not sound like the monophthongized pronunciation of down-[dan].

Other phonological characteristics of Pittsburgh speech are shared with other varieties in the United States. These include monophthongization of /aj/ in some contexts (because /aw/ is also often monophthongal, this means that towel and tile can sound similar, at least to outsiders); the laxing of tense vowels /i/ and /u/ before the liquids /r/ and / $/$ / (so that steel can be realized as [strl]) and elsewhere in at least one word (eagle, realized as [Igəl]); intrusive [r] in some words; and the vocalization of $/ 1 /$. Lexical items thought of as local include gumband 'rubber band', nebby 'nosy', slippy 'slippery', and chipped ham 'thinly sliced ham'. (Most of these can be traced either to the Scotch-Irish substrate of local English or to brand names of locally produced items.) Morphosyntactic characteristics include the use of yinz (also often spelled "yunz") as a second person plural pronoun and the use of the construction represented in This shirt needs ironed or the needs-fixed list (of city streets and bridges). Yes/no questions sometimes end with a fall in intonation rather than the more standard-sounding rise. A discoursemarking feature thought of as local is the sentence-final use of n'at (from "and that") as a "general extender" (Overstreet 1999).

\section{SOURGES OF DATA}

At this stage of our research we were interested in broadly tracking the history of variable (aw) in Pittsburgh rather than exploring its social stratification. Our research questions had to do with when the feature arose, at what rate it spread, and what its future trajectory might be rather than with determining exactly who was using it when and what the social and linguistic mechanisms of its spread might have been. Thus, we focused in this preliminary phase on a subset of speakers that we thought would be most likely to use this feature and to have been using it since its inception. Monophthongal /aw/ is socially stigmatized when it is heard as a marker of social class (although our results suggest that it may carry some "covert prestige" [Trudgill 1972], and, in contexts in which it is employed or heard 
as a marker of local affiliation, it may have some more overt prestige). On the basis of numerous other sociolinguistic studies, as well as observations of Pittsburghers with a range of demographic characteristics, we expected that the population most likely to use monophthongal /aw/ in the most contexts would be white working-class men. (Monophthongal /aw/ is also heard in the speech of working-class women and women and men with other social identifications, although it is rare in local African Americans' speech.) Thus, we examined the use of this feature in the speech of white working-class males over five generations. These men were born during five periods in Pittsburgh history (Baldwin 1937; Lubove 1976):

1. 185 o To 1899 . During this time the population of southwestern Pennsylvania was growing and urbanizing quickly due to industrialization. If there was a "founder generation" (Trudgill 1986) of people from many places whose ways of speaking consolidated into a local norm, it would probably have been the first generation born in Pittsburgh during this period, perhaps in the last quarter of the nineteenth century. Unfortunately, however, the only data we have pertaining to people born in this period come from the rural speakers interviewed by Guy Lowman for the Linguistic Atlas of the Middle and South Atlantic States.

2. 1900 Tо 1919. The economy and population of Pittsburgh continued to grow rapidly during these years, and immigration would have continued to result in language contact. Working-class Pittsburghers of this period were still fairly isolated from people elsewhere, so local norms for speech would not often have been juxtaposed with norms from elsewhere. We might thus expect local speech norms to become stronger and more focused during this period (LePage and Tabouret-Keller 1985).

3. 1920 Tо 1949. The area's population grew somewhat more slowly during this period. The industrial economy was relatively stable and prosperous, as was the increasingly unionized workforce. Increased access to mass media and, during World War II, increased contact between working-class male Pittsburghers and people from elsewhere would have meant increased exposure to external norms for speech.

4. $195^{\circ}$ To 1969. These are members of the "baby boom" generation, more exposed than their forebears to the mass media and more mobile geographically. During this period, the population of Allegheny County began to decline from its peak in $194^{\circ}-5^{\circ}$. The economy was still dominated by heavy industry, in particular steel production.

5. SINCE 1970 . This is the first generation to come of age in a mostly postindustrial Pittsburgh. (Coke and steel production declined dramatically throughout the period, ending in Pittsburgh proper in the 199os, though some steel is still produced in the area.) The area's population has continued to decline. As service industries and more globally connected high- 
tech industries have begun to replace heavy industry, Pittsburghers are now forced to think of themselves and their city in a more global context.

For the pre-19oo speakers, we examined data from the Linguistic Atlas of the Middle and South Atlantic States (LAMSAS; Kretzschmar 1998; see also McDavid et al. 1980-). The LAMSAS interviews from Allegheny County and the contiguous counties-Washington, Westmoreland, Beaver, and Butler-included ten white working-class male informants born between $185^{1}$ and 1896 . Their ethnic backgrounds are unfortunately not provided in the data records, so we cannot tell whether they were recent immigrants. The fact that most were farmers, together with what we know about informant selection for the atlas projects, suggests, however, that they came from the longer-resident Scotch-Irish and German population. One of these informants did not respond to any of the elicited items with a word containing /aw/, so we were left with nine. According to the demographic notes by Lowman, the LAMSAS field-worker, eight of these informants were farmers, and one was a craftsman/foreman; only two had completed some college or trade school. The data provided 64 items with the variable (aw) in the words clouds, clouding up, cloudburst, down, south, southeast, southwest, sundown, and thousand.

For the twentieth-century speakers we examined data from two sets of documentary films and subsequently conducted interviews to supplement the film data. One set of documentary films consisted of a series of training films for use in police academies and law schools, filmed by John Marshall (1970a, 197ob, 1970c) in the late 196os. These films (which were the inspiration for television police dramas such as Hill Street Blues) followed Pittsburgh police officers to the scenes of domestic violence and other crimes, criminal investigations, meetings, and interviews. We assumed that the policemen included in the films were Pittsburghers since the police department hired only locally, and we classified them as working class by virtue of their occupation. We estimated on the basis of their appearance that their ages ranged from 30 to 45 , so they would have been members of the 1920-49 generation. From these films we derived data that represent nine such speakers with 38 instances of the (aw) variable and one additional speaker (a teenaged suspect) born between $195^{\circ}$ and 1969, with 6 instances of the variable.

An additional set of eleven films came from the "Pittsburgh History" series produced by the Pittsburgh Public Broadcasting station, WQED/ Pittsburgh (1989, 1990a, 199ob, 1990c, 1992, 1993, 1994, 1996, 1997, 1998, 1999). Ten of these films were created by Pittsburgh native Rick Sebak. Fortunately for us, Sebak is extremely good at making people talk 
unselfconsciously on film, and since his choices about how to present the city have a distinct working-class bias, they include plenty of relevant data. From these films, we recorded all tokens of words with the variable (aw) from the male speakers we judged to be natives of Pittsburgh, white, and working class, basing our judgments on cues such as dress, location, and what they were doing or talking about in the film. These films provided a sample of working-class male Pittsburghers which included members of all generations born in the twentieth century: 5 born between 1900 and 1919 with 18 items; 24 born between 1920 and 1949 with 144 items; 47 born between $195^{\circ}$ and 1969 with 125 items; and 9 born from 1970 to about 1985 with 16 items. We did not include children in the sample.

Because the films provided many fewer speakers born since 1970 than speakers of the other generations, we conducted "rapid and anonymous" (Labov 1972, 34-69) interviews with members of this generation to supplement the data. We went to construction sites, the Labor Day parade, and various mechanic and auto body repair shops. With the men there who fit our criteria, we conducted brief interviews in which we indirectly tried to elicit words that included the variable (aw). For example, we asked the location of places that are "downtown" and inquired what they did on weekends, with the idea that they might talk about "going out." We taperecorded these interviews so that the situation would be as similar as possible to the situations of the speakers in the films, who were also aware that they were being recorded (and who were also in many cases talking to relative strangers in informal interview settings). The new data provided ten additional speakers born from 1970 to 1981 , with 62 items. Table 1 summarizes all our data.

TABLE 1

Overview of Data

\begin{tabular}{lcccc}
\hline Year of Birth & $\begin{array}{c}\text { Number of } \\
\text { Speakers }\end{array}$ & $\begin{array}{c}\text { Items in Which } \\
\text { /aw/ Is Variable }\end{array}$ & $\begin{array}{c}\text { Items in Which } \\
\text { law/ Is Invariable }\end{array}$ & $\begin{array}{c}\text { Total Items } \\
\text { with /aw/ }\end{array}$ \\
1850-1899 & 9 & 64 & 0 & 64 \\
$1900-1919$ & 5 & 17 & 1 & 18 \\
$1920-1949$ & 33 & 168 & 14 & 182 \\
$1950-1969$ & 48 & 121 & 10 & 131 \\
$1970-$ & 19 & 72 & 6 & 78 \\
TOTAL & 114 & 442 & 33 & 475
\end{tabular}

NOTE: Only items in which /aw/ was variable were included in the analysis. 


\section{FINDINGS}

To analyze the data, tokens of (aw) were identified and categorized acoustically as monophthong [a], diphthong [aw], or an intermediate, partially monophthongized form. The raters, who were students in the course, had previously practiced this procedure as a group in several exercises, both to get experience in the kind of close listening required and to help insure inter-rater reliability, at least in an informal way. During these practice sessions, we also discussed how we would identify the working-class Pittsburghers in the films, taking care not to base our judgments on their speech. Raters were asked to view their films at least once before doing any coding, to identify the working-class male characters to whom they would listen on subsequent passes. To help minimize the possibility of missing some of the tokens and to counteract the bias which is always a risk in impressionistic coding, two raters worked on each of the films in a first pass, and a third rater (Bhasin or Wittkofski) made an additional pass through each.

We then calculated (aw) index scores for each generation by assigning a numerical value to each of these three variants ( 3 for monophthongal [a], 2 for intermediate forms, 1 for standard-sounding [aw]) and multiplying each value by the number of tokens of that variant in the generational group in question. The total was then divided by the total number of items in which (aw) was variable to arrive at the index score for that group. We excluded words such as now and how because it turned out that in our data law/ was invariably pronounced as a diphthong in unchecked syllables.

To see whether the source of the data made a difference in the results, we first calculated the score separately for speakers from the history films born between 1920 and 1949 and compared it to the score of speakers in the police films born between 1920 and 1949. The same process was repeated for speakers in the history films born since 1970 and speakers from the interviews born since 1970. Table 2 displays the results of this procedure.

The identical scores in the case of the youngest speakers allow us to conclude that the different sources of data and collection techniques did not impact the results. The results from the 9 speakers born between 1920 and 1949 in the police films yield a more monophthongal score than do the results from the 24 speakers in the Pittsburgh history films from this generation. Because of the relatively small number of speakers and tokens in the police films in comparison to the history films, however, the score for this generation when only speakers from the history films are included, 2.53 , is only slightly lower than the combined score of 2.59 . We thus 
TABLE 2

Comparison of Data Sources for Speakers Born in 1920-49 and in 1970 or Later

$\begin{array}{lrc} & \text { Number of Tokens } & \text { Index Score } \\ \text { 1920-1949 } & & \\ \text { History films } & 131 & 2.53 \\ \text { Police films } & 37 & 2.81 \\ \text { 1970- } & & \\ \text { History films } & 16 & 2.25 \\ \text { Interviews } & 56 & 2.25\end{array}$

combined the speakers from all the data sources for our overall analysis. Figure 1 graphs the overall scores. An index score of 1.0 represents $100 \%$ usage of the diphthongal [aw] variant of the variable (aw); an index score of 3.0 would represent $100 \%$ usage of the monophthongal [a] variant.

There is no evidence of monophthongization in the LAMSAS data for speakers born before 19oo. It is possible that Lowman missed evidence of monophthongal /aw/ because he was not expecting to hear it. As Labov points out, "Dialectologists in the field are often quite conservative in their notation, and they tend to limit their entries to variants of the forms they have encountered before, even when sound changes have advanced across several levels of the sound system" $(1994,74)$. However, the level of detail of Lowman's transcriptions suggests otherwise. In every case, /aw/ is transcribed with two vowel symbols, the first usually [a] but sometimes [æ] and the second $[\mathrm{u}]$. A variety of diacritics for height, length, and nasalization

FIGURE 1

Changes in Monophthongal /aw/ Usage across Five Generations of Working-Class Pittsburgh Men

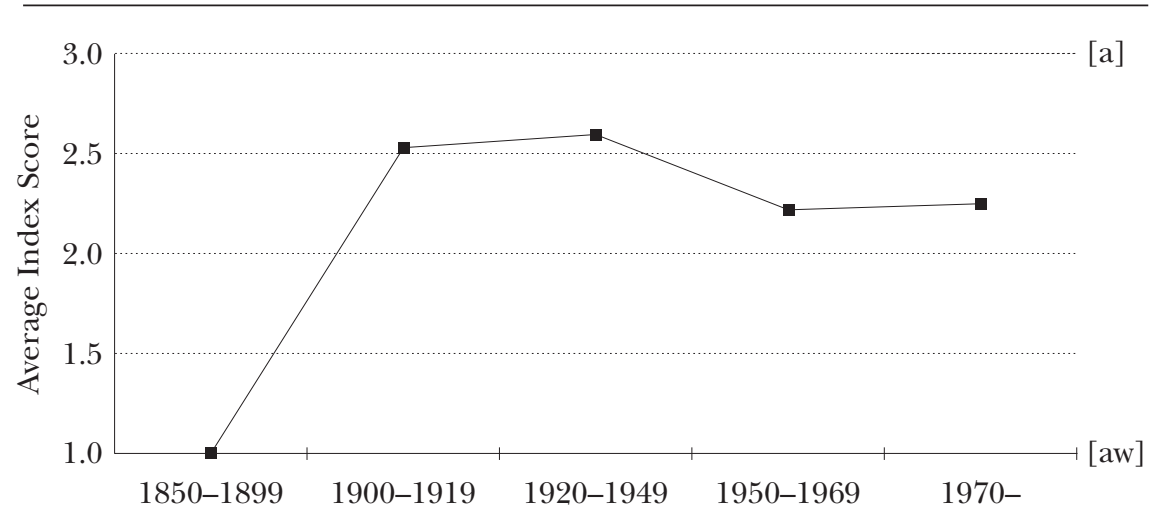


suggests that Lowman was attending to the details of these sounds carefully enough to have noticed if they were monophthongized. Here are three of Lowman's transcriptions of down, for example:

$$
\begin{aligned}
& d a^{\wedge} \cdot U^{\vee} n \\
& d a^{\wedge} \cdot \tilde{U} n \\
& d a^{>} u n
\end{aligned}
$$

Lowman's informants, all of whom but one were farmers, were most likely to have been of Scotch-Irish or German background, and while evidence about how they would have sounded is sparse and indirect, there is no suggestion that monophthongized /aw/ would have been likely in either case. Written evidence that might suggest how Scotch-Irish immigrants sounded includes the poetry of David Bruce (1 740 ? -1 830), of Washington County, Pennsylvania, who wrote "under the signature of the Scots-Irishman," as he put it, though he may actually have been from Scotland rather than from northern Ireland (Gilmore 1999, 84-98). Nonstandard spellings such as dowre 'dour', faund 'found', housie 'diminutive of house', and mou' 'mouth' represent /aw/ as a diphthong. But Bruce was using an already established conventional orthography for Scots, so these spellings are extremely unlikely to reflect either eighteenth-century pronunciation in Scotland or Pennsylvania Scotch-Irish pronunciation.

Our data show that the generation born from 1900 to 1919 was, however, already monophthongizing /aw/. Although we do not have detailed demographic information about these speakers, it is likely that many of them are the descendants of nineteenth-century immigrants to the area rather than of earlier Scotch-Irish or German immigrants. The use of the monophthongal variant of /aw/ peaks in the interwar generation and falls somewhat among the baby boom generation. But it is still very much in use among the youngest speakers. Working-class male Pittsburghers between the ages of about 15 and 3 o seem to be monophthongizing somewhat more than the previous generation does, though the difference is small $\left(2.25^{\mathrm{O}}\right.$ vs. 2.223).

\section{DISGUSSION}

These results, preliminary though they are, raise several questions and suggest directions for further work. In the first place, if monophthongal law/ is indeed a twentieth-century innovation, we would like to know where it came from. Second, we would like to be able to unpack the reasons for its persistence. 
WHERE DID MONOPHTHONGAL /aw/ COME FROM? If we assume that Lowman's transcriptions reflect the fact that his rural working-class nineteenth-century male informants did not monophthongize /aw/, it remains to be determined when monophthongal /aw/ entered the local repertoire and where it came from. The emergence of monophthongal /aw/ appears to be roughly coeval with rapid immigration to and urbanization of the area at the end of the nineteenth century. The fact that most of the newcomers to the city were not from the surrounding region would have heightened the probability that city dwellers, focused inward in tight neighborhood and workplace social networks and with relatively little contact with the countryside, might have developed new ways of doing things that would differentiate them from the rural population. One possibility for how this might have happened in the case of the monophthongization of /aw/ is that monophthongal /aw/ may have resulted from language contact. We would not be the first to suggest that some features of Midland speech might be traceable to the immigration that came with industrialization. Herold (1990, 1997) studied a coal-mining town in eastern Pennsylvania where some speakers merge /a/ and / $/$ / the way some Pittsburgh speakers do, finding that the sudden expansion of the merger coincided with the immigration of large numbers of speakers of Slavic languages (particularly Polish). Herold could not suggest, however, what the linguistic connection might have been, since Polish in fact has contrasting back vowels. The possibility is also raised in Herold's work that monophthongal /aw/ may also be a result of language contact, but Labov (2001, 256) summarizes by saying that "no convincing connection has yet been found between a Polish substratum and the merger ... or monophthongization of /aw/."

WHY DOES MONOPHTHONGAL /aw/ PERSIST? Monophthongal /aw/ is clearly the object of local stereotyping, at least in some contexts. When Pittsburghers talk informally about what characterizes "Pittsburghese," they tend to mention the syntactic and morphological peculiarities that come to the fore when people are taught to write in standard English, rather than features of the local accent. People with strong local accents are sometimes referred to as "yinzers," for example, after the locally used second person plural pronoun "yinz." In written representations of local speech, however, monophthongal /aw/ plays a dominant role. Monophthongal /aw/, especially but not exclusively in the word downtown (almost invariably spelled "dahntahn"), is consistently depicted as one of the most typical features of the local accent.

To begin to explore the communicative processes that lead to stereotyping and develop hypotheses about the possible connections between 
stereotyping and the persistence or loss of local-sounding features, we conducted a study of written representations of Pittsburgh speech. By a "written representation" we mean the use of some nonstandard word, structure, or spelling that claims to capture some feature of what Pittsburghers sound like or say. For the present analysis, we looked at a corpus of 190 representations intended as fleeting evocations of local speech in the context of discourse on other subjects. (There are also a number of larger collections, organized like dictionaries, whose purported function is to describe the variety as a whole. These include books like How to Speak Like a Pittsburgher (McCool 1982) and a Web site (http:// www.pittsburghese.com) on which people contribute to an alphabetical listing of "Pittsburghese" words. These were excluded from the present analysis, however.) This sample includes the following:

1. Articles, headlines, letters to the editor, cartoons, and columns from the Pittsburgh Post-Gazette. Almost all of these occur in connection with topics that have a strong local link and about which people are not being completely serious. For example, political cartoons about the city transit system sometimes depict buses or light-rail cars with the destination "Dahntahn," articles about the local football and baseball teams sometimes call them the "Stillers" (Steelers) and the "Pahrts" (Pirates), respectively, and an April Fools Day article in the Food section is headlined "Fast food, cheap wine and yunz." Occasionally, local-sounding speech is represented in contexts that appear not to be humorous, as when the principal of a school in which some students had circulated death threats is quoted as saying "They said they were just jagging around ['fooling around']."

2. Several articles from Pittsburgh magazine, also typically humorous, including, for example, one about a local radio personality "jaggin' around" and one by a skeptical reporter invited on a cruise on a formerly polluted river, who writes, "A pleasure trip? On the Mon? Git ahta tahn" ('Get out of town', an expression associated with a former city mayor who had a strong local accent).

3. An anonymous "Pittsburghese" version of "Santa Claus Is Coming to Town" ("Santa Clause Is Commin' Dahntahn"), which was widely circulated via email

4. A joke book called Are You a Real Pittsburgher? (Schuman 1995), which includes several jokes based on representations of local speech. For example, one page asks readers to match pictures of various marine creatures with the labels Rainbow Trot 'trout', Killer Well 'whale', and Lectric ill 'electric eel', and on another page the correct answer to the question "A pond is ..." is "sixteen ounces" rather than "a small lake."

5. A flyer from the Giant Eagle supermarket chain with a section introducing the chain's new mascot, Iggle (Eagle) 
6. Annie Dillard's ( $\left.19^{8} 7\right)$ memoirs, in which she recollects her mother's using archaic-sounding "Scotticisms" like gummy 'rubber band' or poke 'bag'

7. A sweatshirt, intended for sale at tourist sites, a refrigerator magnet, and a postcard that all superimpose examples of "Pittsburghese," such as Imp'n Arn 'shot of Imperial whisky and an Iron City beer'; jumbo, a local word for 'bologna sausage'; and nebby 'nosy' on skyline views of the city

8. A message painted on a fence by students saying farewell to graduating friends whom they address as "yinz"

The sampling technique consisted of collecting every written representation of local speech to which the first author was exposed over the course of three years. If the same feature was represented the same way more than once in a single source, it was counted only once. Thus we have probably ended up with a roughly representative sample of what it is about "Pittsburghese" that gets represented via re-spelling, and how it is represented.

Representations of monophthongal /aw/, usually spelled "ah" as in "clahdy" for cloudy or "aht" for out, account for $21.0 \%$ of the tokens in the corpus. Monophthongal /aw/ is stereotyped in writing, in other words, almost three times more frequently than any other feature. (Second most frequent at $8.4 \%$ is the pronunciation of the morpheme $-i n g$ as $/ \mathrm{In} /$, and third at $6.8 \%$ is laxed /i/ before / $/$ /, as in "Stillers" for Steelers. It is interesting to note that monophthongal /aw/ is the only one of all the phonological features that are stereotyped in written representations that is truly local, in the sense that it has rarely been noted elsewhere.) Pittsburghers thus tell each other over and over that "real" Pittsburghers say things like "dahntahn."

A number of recent studies have suggested that, at least to a certain extent, the leveling forces of increased dialect contact (Trudgill 1986), which encourage people to sound more like people elsewhere via linguistic accommodation, may be counteracted by attempts to cling to local identity by preserving at least one or two features that sound local (Wolfram and Schilling-Estes 1998, 1 16-17). Sounding local—sounding, in other words, as if one has a legitimate connection to a place-can serve a variety of public and personal functions. Sociolinguists have long known that inmigration can make insider/outsider differences salient in new ways and lead to linguistic divergence between people whose interests and identities are linked with the outside and those whose interests and identities are linked with the local. Labov (1963) showed this in Martha's Vineyard, for example. More recently, work by Bailey (1991) and his colleagues (Tillery 1997) shows that Texans who strongly identify with the state are more likely than others to use features that differentiate their speech from that of people from elsewhere. Massive migration to Texas from the North during 
the second half of the twentieth century has accordingly led Texans' speech to become more different, in some respects, from outsiders' speech, rather than more similar. Linguistic performances of localness may arise in the context of tourism and other kinds of in-migration, temporary or permanent. Schilling-Estes (1998) shows how Ocracokers' interactions with outsiders can lead to the focusing of dialect difference around exaggerated realizations of a particular sound. Dyer (2000) and Eckert (2000), among others, have explored the ways in which people with different roles in local social structures and economies are motivated to express more or less local linguistic identities. Studies in several locations (Beal 1999; Milroy and Watt 1999; Røyneland 200o) suggest that dialect leveling may lead not to national or global norms but to regional ones. This has to do with the fact that ways of talking that are ideologically linked with places continue to play important economic and psychological roles in human life, sometimes as a reaction to globalization (Mugerauer $198_{5}$; Silverstein 1998; Johnstone 1999).

Representations of local speech are, we think, a key part of the process by which the members of a community come to share ideas about what sounds local and what it means to sound local. This is because parodies, performances, and other representations are the mechanism by which people tell each other what sounds local. Repeated representations of particular nonstandard features as being particularly typical or authentic have the effect of focusing attention on them, and eventually, perhaps, in focusing the remnants of otherwise receding nonstandard dialects around them. Thus, representations of "Pittsburghese," both written ones and oral imitations, may be part of the mechanism by which particular features (such as monophthongal /aw/) come to sound local and thus become resources for the expression of local identity, while other features do not, and hence may pattern differently. It is possible, in other words, that there is not just a coincidental relationship between the fact that monophthongal law/ is persisting, perhaps even increasing in use, and the fact that it is so often portrayed in representations of local speech. Although we cannot yet demonstrate it, we think there may be a causal connection between the historical trajectory of this feature and its key role in local ideology about what it takes to "speak Pittsburghese."

In further work we will be testing this hypothesis. This will require several kinds of work. For one thing, it will be important to compare the trajectory of monophthongal /aw/ with that of other features that do not appear as often in representations of local speech, such as vocalized /1/ (which is commented on locally, but less frequently) or the pronunciation of the merged low back vowel as a rounded [o] (which is almost never the 
topic of remark, in part because representations of speakers' using the "wrong" sound in a set that is merged are funny only to people who do not themselves merge the sounds). Since there are other factors in play, such as the relative salience of the features and their roles in the phonological system as a whole and in larger processes such as chain shift, and since there are also other social correlates for variation, such as characteristics of speakers' social networks (Milroy 1987), disentangling the role of representations of linguistic features in the processes of variation and change will require the use of techniques for multivariate analysis. It will also require larger-scale sociolinguistic work in Pittsburgh in which a representative sample of speakers and a much larger inventory of features are studied in systematic ways. For another thing, we would like to know where conventional representations of dialect come from, how they are circulated, and whom they affect and by what social and economic mechanisms. To do this will require a combination of historical, ethnographic, and discourse analytic techniques.

Much more other work about Pittsburgh speech needs to be done. For example, tracking down the origin of monophthongal /aw/, which would require new sources of historical and comparative data, would contribute to the understanding of the development of English in the United States. We hope the study we have reported on here, limited and exploratory as it is, will encourage further exploration.

\section{NOTE}

We would like to thank the Carnegie Mellon University students who helped us frame this project and do the preliminary analysis: Natalia Beylis, Emma Esmaili, Christopher Grant, Sayaka Kanade, Ann Lin, Alia Pustorino, Lisa Rump, Eric Spaulding, and Danielle Zawodny Wetzel. Donald Brenneis first told us about the John Marshall Pittsburgh police films. We presented an earlier version of this paper at NWAV 29 in October 2000 and are grateful to that audience for encouragement. Subsequently, we have greatly benefited from advice from William Labov, Michael Montgomery, and two readers for American Speech.

\section{REFERENCES}

Bailey, Guy. 1991. "Directions of Change in Texas English." Journal of American Culture 14: 125-34.

Bailey, Guy, Tom Wikle, Jan Tillery, and Lori Sand. 1993. "Some Patterns of Linguistic Diffusion." Language Variation and Change 3: 359-9o. 
Baldwin, Leland D. 1937. Pittsburgh: The Story of a City. Pittsburgh: Univ. of Pittsburgh Press.

Beal, Joan C. 1999. “Geordie Nation': Language and Regional Identity in the North-East of England." Paper presented at the Tenth Conference on Methods in Dialectology, St. John's, Newfoundland, 1-6 Aug.

Brown, Cynthia. 1982. "A Search for Sound Change: A Look the Lowering of Tense Vowels before Liquids in the Pittsburgh Area." M.A. thesis, Univ. of Pittsburgh.

Dillard, Annie. 1987. An American Childhood. New York: Harper and Row.

Dunaway, Wayland F. 1944. The Scotch-Irish of Colonial Pennsylvania. Chapel Hill: Univ. of North Carolina Press.

Dyer, Judy. 200o. “We All Speak the Same Round Here': Dialect Leveling in a Scottish-English Community." Paper presented at the Sociolinguistic Symposium 2000, University of the West of England, Bristol, 27-29 Apr.

Eckert, Penelope. 2000. Linguistic Variation as Social Practice: The Linguistic Construction of Identity in Belten High. Oxford: Blackwell.

Gagnon, Christina L. 1999. "Language Attitudes in Pittsburgh: 'Pittsburghese' versus Standard English.” M.A. thesis, Univ. of Pittsburgh.

Gilmore, Peter. 1999. "Scots-Irish" Words from Pennsylvania's Mountains. Bruceton Mills, W.Va.: Scotpress.

Hankey, Clyde T. 1965a. “'Tiger,' 'Tagger,' and [ar] in Western Pennsylvania." American Speech 40: 226-28.

- 1965 b. "Diphthongal Variants of $[\varepsilon]$ and $[æ]$ in Western Pennsylvania." American Speech 40: 228-29.

—. 1972. "Notes on West Penn-Ohio Phonology." In Studies in Linguistics in Honor of Raven I. McDavid, Jr., ed. Lawrence M. Davis, 49-61. University: Univ. of Alabama Press.

Herold, Ruth. 1990. "Mechanisms of Merger: The Implementation and Distribution of the Low Back Merger in Eastern Pennsylvania." Ph.D. diss., Univ. of Pennsylvania.

—_ 1 1997. "Solving the Actuation Problem: Merger and Immigration in Eastern Pennsylvania." Language Variation and Change 9: 149-64.

Johnstone, Barbara. 1999. "The Individual and the Local: Methodological Implications." Paper presented at Methods in Sociolinguistics: A Coference in Honor of Ronald Macaulay, Claremont, Calif., 1 2-1 4 Nov.

Johnstone, Barbara, and Andrew Danielson. 2001. "Pittsburghese' in the Daily Papers, 1910-2001: Historical Sources of Ideology about Variation.” Paper presented at the 3 oth conference on New Ways of Analyzing Variation (NWAV 30), Raleigh, N.C., 11-14 Oct.

Kretzschmar, William, Jr., ed. 1998. "Linguistic Atlas of the Middle and South Atlantic States." In Linguistic Atlas Projects (Web site). Accessed 11 Mar. 2000. Available from http://us.english.uga.edu/lamsas.

Kurath, Hans. 1949. A Word Geography of the Eastern United States: Based upon the Collection of the Linguistic Atlas of the Eastern United States. Ann Arbor: Univ. of Michigan Press. 
Kurath, Hans, and Raven I. McDavid, Jr. 1961. The Pronunciation of English in the Atlantic States. Ann Arbor: Univ. of Michigan Press.

Labov, William. 1963. "The Social Motivation of a Sound Change." Word 19: 237309.

- 1972. Sociolinguistic Patterns. Philadelphia: Univ. of Pennsylvania Press.

- 1994. Principles of Linguistic Change. Vol. 1, Internal Factors. Oxford: Blackwell. . 2001. Principles of Linguistic Change. Vol. 2, Social Factors. Oxford: Blackwell.

Lane, Lisa Ann. 1998. "Emergence and Transformation of a Dialect: Thyborønsk (Danish).” Ph.D. diss., Univ. of Chicago.

Le Page, R. B., and Andrée Tabouret-Keller. 1985. Acts of Identity: Creole-Based Approaches to Language and Ethnicity. Cambridge: Cambridge Univ. Press.

Lubove, Roy, ed. 1976. Pittsburgh. Documentary History of American Cities. New York: New Viewpoints.

Marshall, John. 1970a. Forty Dollar Misunderstanding. Pittsburgh Police Film Series. $8 \mathrm{~min}$. Watertown, Mass.: Documentary Educational Resources. Videocassette.

— 1970b. Inside/Outside Station Nine. Pittsburgh Police Film Series. 9o min. Watertown, Mass.: Documentary Educational Resources. Videocassette.

—. 1970c. 901/904. Pittsburgh Police Film Series. 65 min. Watertown, Mass.: Documentary Educational Resources. Videocassette.

McCool, Sam. 1982. Sam McCool's New Pittsburghese: How to Speak Like a Pittsburgher. Pittsburgh: Hayford.

McDavid, Raven I., Jr., et al. 1980-. Linguistic Atlas of the Middle and South Atlantic States. 2 vols. to date. Chicago: Univ. of Chicago Press.

McElhinny, Bonnie. 1999. "More on the Third Dialect of English: Linguistic Constraints on the Use of Three Phonological Variables in Pittsburgh." Language Variation and Change 1 1: 171-95.

Milroy, Lesley. 1987. Observing and Analyzing Natural Language: A Critical Account of Sociolinguistic Method. Oxford: Blackwell.

Milroy, Lesley, and Dominic J. Watt. 1999. "Patterns of Variation and Change in Three Tyneside Vowels: Is This Dialect Levelling?" In Urban Voices: Accent Studies in the British Isles, ed. Paul Foulkes and Gerard Docherty, 25-46. London: Arnold.

Mugerauer, Robert. 1985. "Language and Environment." In Dwelling, Place, and Environment: Towards a Phenomenology of Person and World, ed. David Seamon and Robert Mugerauer, $5^{1-70}$. Dordrecht: Nijhoff.

Overstreet, Maryann. 1999. Whales, Candlelight, and Stuff Like That: General Extenders in English Discourse. Oxford: Oxford Univ. Press.

Røyneland, Unn. 200o. "Dialect Levelling in Norway: A Process of Regionalization or Standardization?" Paper presented at the Sociolinguistics Symposium 2000, University of the West of England, Bristol, 27-29 Apr.

Schilling-Estes, Natalie. 1998. "Investigating 'Self-Conscious' Speech: The Performance Register in Ocracoke English.” Language in Society 27:53-83.

Schuman, Eric. 1995. Are You a Real Pittsburgher? The Official Joke Book for Pittsburghers Only. Carnegie, Pa.: ABELexpress. 
Silverstein, Michael. 1998. "Contemporary Transformations of Local Linguistic Communities." Annual Review of Anthropology 27: 401-26.

Tillery, Jan. 1997. "The Role of Social Processes in Language Variation and Change." In Language Variety in the South Revisited, ed. Cynthia Bernstein, Thomas Nunnally, and Robin Sabino, 434-46. Tuscaloosa: Univ. of Alabama Press.

Trudgill, Peter. 1972. "Sex and Covert Prestige: Linguistic Change in the Urban Dialect of Norwich." Language in Society 1: 1 79-95.

- 1986. Dialects in Contact. Oxford: Blackwell.

U.S. Census Bureau. 2001a. "Incorporated Places of 100,000 or More in Alphabetic Sort, with 1990 and 2000 Population, and Numeric and Percent Change: 1990 to 200o." In U.S. Census Bureau Home Page (Web site). Accessed 25 June 2001. Available from http://blue.census.gov/population/cen200o/phc-t5/ tabo 1.pdf.

- 2001b. "Counties in Alphabetic Sort within State, 1990 and 2000 Population, Numeric and Percent Change: 1990 to 200o." In U.S. Census Bureau Home Page (Web site). Accessed 25June 2001. Available from http://blue.census.gov/ population/cen200o/phc-t4/tabo1.pdf.

Wolfram, Walt, and Natalie Schilling-Estes. 1998. American English: Dialects and Variation. Malden, Mass.: Blackwell.

WQED/Pittsburgh. 1989. The Spirit of Pittsburgh. Narrated by Fritz Weaver. Produced and written by Peter Argentine. Pittsburgh History Series. 35 min. Pittsburgh: WQED Public Television, QED Communications. Videocassette.

— 1990a. Holy Pittsburgh! Produced, written, and narrated by Rick Sebak. Directed by J. Michael Schafer. Pittsburgh History Series. 6o min. Pittsburgh: WQED Public Television, QED Communications. Videocassette.

- 199ob. Kennywood Memories. Produced, written, and narrated by Rick Sebak. Directed by Allen Rosen. Pittsburgh History Series. 6o min. Pittsburgh: WQED Public Television, QED Communications. Videocassette.

- 1990c. Things That Aren't There Anymore, Volume I. Produced, written, and narrated by Rick Sebak. Directed by Steve Willing. Pittsburgh History Series. 6o min. Pittsburgh: WQED Public Television, QED Communications. Videocassette.

- 1992. Downtown Pittsburgh. Produced and directed by Rick Sebak. Pittsburgh History Series. 6o min. Pittsburgh: WQED Public Television, QED Communications. Videocassette.

- 1993. The Mon, the Al, and the O. Produced and narrated by Rick Sebak. Pittsburgh History Series. 6o min. Pittsburgh: WQED Public Television, QED Communications. Videocassette.

— 1 1994. Houses around Here. Produced and narrated by Rick Sebak. Pittsburgh History Series. 6o min. Pittsburgh: WQED Public Television, QED Communications. Videocassette.

- 1996. The Strip Show. Produced, written, and narrated by Rick Sebak. Pittsburgh History Series. 88 min. Pittsburgh: WQED Public Television, QED Communications. Videocassette. 
. 1997. North Side Story. Produced, written, and narrated by Rick Sebak. Pittsburgh History Series. 6o min. Pittsburgh: WQED Public Television, QED Communications. Videocassette.

— 1 1998. South Side. Produced, written, and narrated by Rick Sebak. Directed by Carolyn Wean. Pittsburgh History Series. 6o min. Pittsburgh: WQED Public Television, QED Communications. Videocassette.

- 1 1999. Things That Are Still Here. Produced, written, and narrated by Rick Sebak. Pittsburgh History Series. go min. Pittsburgh: WQED Public Television, QED Communications. Videocassette.

- 2001. "Population of Pittsburgh and Allegheny County over Time." In WQED Pittsburgh Home Page (Web site). Accessed 25 June 2001. Available from http://www.wqed.org/erc/pghist/units/WPAhist/pop_growth.html. 